\title{
Reproductive performance of catfish Clarias sp. with probiotics Bacillus sp. NP5 addition through feed
}

\section{Performa reproduksi ikan lele Clarias sp. yang diberi probiotik Bacillus sp. NP5 melalui pakan}

\author{
Safira Qisthina Ayuningtyas ${ }^{1}$, Muhammad Zairin Jr $^{1^{*}}$, Widanarni ${ }^{1}$ \\ 'Department of Aquaculture, Faculty of Fisheries and Marine Sciences, IPB University, Bogor, West Java, \\ Indonesia 16680 \\ *Corresponding author: zairinmz@live.com
}

(Received September 5, 2017; Accepted September 11, 2019)

\begin{abstract}
The aim of this study was to evaluate the reproductive performance of catfish given probiotics Bacillus sp. NP5 with different concentrations through feed. This study used a completely randomized block design (CRBD) with the administration of probiotic Bacillus sp. NP5 at $2 \%$ concentration of $10^{8} \mathrm{CFU} / \mathrm{mL}$ and $10^{10} \mathrm{CFU} / \mathrm{mL}$ in feed given and control (without probiotics), then repeated four times. Catfish broodstocks with an average size of $955 \pm 261.27 \mathrm{~g}$ were kept in a net sized $1 \mathrm{~m} \times 1 \mathrm{~m} \times 1 \mathrm{~m}$ with seven broodstocks per net. Parameters observed included the Gonadosomatic Index (GSI), fecundity, number of matured eggs, frequency distribution of egg diameter, fertilization rate, and hatching rate. The result showed that the GSI value of female catfish broodstock was significantly different in sixth week as the highest value was obtained from $10^{10} \mathrm{CFU} / \mathrm{mL}$ probiotics with $5.19 \%$. Moreover, the fecundity of all treatments showed significantly different results $(\mathrm{P}<0.05)$ as the highest value was on the concentration of $10^{10} \mathrm{CFU} / \mathrm{mL}$ Bacillus sp. NP5 with 137,123 $\pm 32,635$ eggs/broodstock. This study concludes that the administration of probiotics Bacillus sp. NP5 with $10^{10} \mathrm{CFU} / \mathrm{mL}$ in feed given to catfish broodstock increases the fecundity (137,123 eggs/broodstock), GSI (5.19\%), number of matured eggs percentage $(64.50 \%)$, and hatching rate $(82.53 \%)$.
\end{abstract}

Keywords: Bacillus sp. NP5, catfish, reproductive performance

\begin{abstract}
ABSTRAK
Tujuan penelitian ini adalah mengevaluasi performa reproduksi ikan lele yang diberi probiotik Bacillus sp. NP5 dengan konsentrasi berbeda melalui pakan. Penelitian ini menggunakan rancangan acak kelompok lengkap (RAKL) dengan pemberian probiotik Bacillus sp. NP5 pada konsentrasi $10^{8} \mathrm{CFU} / \mathrm{mL}$ dan $10^{10} \mathrm{CFU} / \mathrm{mL}$ sebanyak $2 \%$ dari pakan yang diberikan serta kontrol (tanpa pemberian probiotik), masing-masing dengan empat ulangan. Induk ikan lele dengan ukuran $955 \pm 261.27 \mathrm{~g}$ dipelihara pada jaring hapa ukuran $1 \mathrm{~m} \times 1 \mathrm{~m} \times 1 \mathrm{~m}$ sebanyak tujuh ekor per jaring hapa. Parameter yang diamati meliputi indeks kematangan gonad (IKG), fekunditas, jumlah telur matang, sebaran frekuensi diameter telur, derajat pembuahan, dan derajat penetasan. Hasil penelitian menunjukkan bahwa nilai IKG induk betina ikan lele berbeda nyata pada minggu keenam dengan nilai tertinggi diperoleh pada perlakuan probiotik $10^{10} \mathrm{CFU} / \mathrm{mL}$ yaitu sebesar $5.19 \%$. Selain itu, fekunditas semua perlakuan menunjukkan hasil yang berbeda nyata $(\mathrm{P}<0.05)$ dengan nilai tertinggi pada perlakuan pemberian probiotik Bacillus sp. NP5 dengan konsentrasi $10^{10} \mathrm{CFU} / \mathrm{mL}$ sebesar 137,123 $\pm 32,635$ telur/induk. Kesimpulan, pemberian probiotik Bacillus sp. NP5 dengan konsentrasi $10^{10} \mathrm{CFU} / \mathrm{mL}$ melalui pakan kepada induk ikan lele mampu meningkatkan nilai fekunditas 137,123 telur/induk, GSI 5,19\%, persentase jumlah telur matang 64,50\%, dan derajat penetasan telur $82,53 \%$.
\end{abstract}

Kata kunci: Bacillus sp., ikan lele, performa reproduksi 


\section{INTRODUCTION}

Clarias sp. catfish is one of important aquaculture commodities that is mostly cultured in Indonesia. This catfish is obtained from male African catfish Clarias gariepinus and female Taiwanese catfish Clarias fuscus crossing (Iswanto, 2013). The average production of catfish in Indonesia increases continuously as an increased production of $19.39 \%$ was produced in 2014-2016 (KKP, 2017). An effort to improve the production can be performed through an intensive to super-intensive culture through the increased stocking density, which respectively increases the seed requirement.

One method to increase the number of seeds is by inducing the broodstock reproduction performance. Nadio (2015) reported that a microbial-based catfish broodstock rearing with biofloc technology could improve the catfish broodstock reproduction performance by accelerating the gonad maturation recovery (rematuration). A broodstock rearing with biofloc technology only required four- week period of rematuration process, while control treatment was until seven-week period. Another parameter, such as gonadosomatic index (GSI), showed a higher value in biofloc treatment than control. Moreover, biofloc technology was also proven to produce more fecundity value twice than control treatment.

Widanarni et al. (2012) also stated that biofloc technology in a Nile tilapia intensive culture could improve the production, water quality, and reproduction. Ekasari et al. (2015) reported that the biofloc technology could improve the average weight, GSI, and fecundity level of Nile tilapia broodstock until 1,243 \pm 217 eggs/broodstock compared to control treatment with $890 \pm 73$ eggs/ broodstock, while the hepatosomatic index (HIS) and egg diameter were insignificantly different. Emerenciano et al. (2012) reported that biofloc technology could improve spawning performance of blue shrimp Litopenaeus stylirostris. In this study, male and female broodstock weight with biofloc treatment was higher than control treatment. The number of eggs per gram weight on each spawning was insignificantly different between biofloc and control, however the broodstock gonad maturation level given biofloc treatment was higher $(3.6 \pm 0.8)$ than control (2.5 \pm 0.5 ). Furthermore, the latent period of spawning (one spawning period to another) in biofloc treatment was faster $(7.4 \pm 1.8$ days $)$ than control
$(10.7 \pm 4.6$ days $)$. Meanwhile, Emerenciano et al. (2014) stated that biofloc technology did not influence the spawning performance of pink shrimp Farfantepenaeus duorarum, except producing a greater egg $(268 \pm 1.6 \mu \mathrm{m})$ than control $(258 \pm 0.5 \mu \mathrm{m})$.

Another microbial-based culture that is potentially studied to improve the reproduction performance is a probiotic administration. Probiotics are living microbes that provides a beneficial influence for the culture organisms due to the capability of modifying the microbial community, repairing the nutrient value, maintaining the host response against diseases, controlling the environment quality (Cruz et al. 2012), and induce the immune response (Nayak, 2010). Probiotics in fish culture is often utilized as a growth promoter and pathogen inhibitor, as well as maintaining the feed digestibility, water quality, and stress tolerance (Cruz et al., 2012). The use of probiotics to maintain the reproduction performance and gamete quality in fish culture are still limited. Cruz et al. (2012) reported that probiotics Bacillus subtilis could maintain the reproduction performance of guppy Poecilia reticulata and platy Xiphoporus maculatus.

A previous study performed by Gioacchini et al. (2011) showed that probiotics Lactobacillus rhamnosus could improve the gonad development containing growth, gonad maturation phase, and fecundity level of zebra fish Danio rerio. The aim of this study was to evaluate the reproduction performance of catfish given probiotic Bacillus sp. NP5 through feed. This study result is expected to become an alternative method to improve the reproduction performance of catfish with the administration of probiotics through feed.

\section{MATERIALS AND METHOD}

\section{Period and location}

The study was performed on February, 2017 until January, 2018 in the experimental pond station, Faculty of Fisheries and Marine Sciences, Institut Pertanian Bogor.

\section{Experimental design}

The study used a completely randomized block design (CRBD) with the administration of probiotic Bacillus sp. NP5 at $2 \%(\mathrm{v} / \mathrm{w})$ concentration of $10^{8} \mathrm{CFU} / \mathrm{ml}$ and $10^{10} \mathrm{CFU} /$ $\mathrm{ml}$ in feed and control (without probiotic administration), then repeated four times. The 
following table shows the experimental design used in this study with the administration of probiotic Bacillus sp. NP5 (Table 1).

Table 1. The experimental design of probiotic Bacillus sp. NP5 administration on catfish broodstock through feed

\begin{tabular}{cc}
\hline Treatment & Description \\
\hline A (control) & $\begin{array}{c}\text { Feed without Bacillus sp. NP5 } \\
\text { administration }\end{array}$ \\
B & Feed with Bacillus sp. NP5 $10^{8} \mathrm{CFU/}$ \\
& mL administration \\
C & Feed with Bacillus sp. NP5 10 $10^{10} \mathrm{CFU} /$ \\
& mL administration \\
\hline
\end{tabular}

\section{Rearing media and fish preparation}

This study used 12 nets sized $1 \mathrm{~m} \times 1 \mathrm{~m} \times 1$ $\mathrm{m}$ placed on a pond with the temperature of $27-$ $30^{\circ} \mathrm{C}$. The fish used were catfish broodstocks with the average size of $955 \pm 261.27 \mathrm{~g}$ obtained from Catfish and Striped Catfish Development and Stock Inducement Center, Cijengkol, Subang, West Java. The broodstocks used in this study were seven female broodstocks per net, therefore the total broodstocks used were 84 fish. Fish were acclimatized based on media and water quality condition for a week during the initial rearing period fed with a commercial feed as much as $2 \%$ of biomass and no Bacillus sp. NP5 administration.

\section{Broodstock rearing}

Before rearing, the catfish broodstocks were selected and artificially spawned to equalize the initial reproduction status. The artificial spawning was performed using a hormone mixture of gonadotropin releasing hormone analog and domperidone (Ovaprim Syndel Lab. Ltd., Canada). The female broodstock eggs were stripped after 12 hours of hormone injection. The female broodstocks were distributed into a recovery medium for 24 hours, then moved into the experimental media and reared until their gonads were matured. Sampling was performed every three weeks to observe the gonad maturation and other parameters.

\section{Probiotic preparation}

The probiotics used in this study were Bacillus sp. NP5 bacteria obtained from the laboratory of fish health, Department of Aquaculture, IPB. Bacillus sp. NP5 bacteria were prepared by culturing these bacteria in a tryptic soy broth (TSB) as much as $10 \mathrm{~mL}$ to obtain $10^{10} \mathrm{CFU} /$
$\mathrm{mL}$ concentration (bacteria stock). Bacillus sp. NP5 bacteria from the stock solution were taken as much as $1 \mathrm{~mL}$ and moved into a polyethylene tube, then centrifuged for five minutes at 3000 $\mathrm{rpm}$. The bacterial cell pellet was added with 1 mL PBS (phosphate buffer saline) solution and diluted to obtain a concentration based on the given treatments in this study.

\section{Feed preparation}

The feed used in this study was a commercial feed for broodstocks with $38 \%$ protein contents. The feed treatments were made by administering the Bacillus sp. NP5 based on the given concentrations. Probiotics were mixed with the feed by adding $3 \%(\mathrm{v} / \mathrm{w})$ of egg whites, then air dried to decrease the humidity. A commercial feed was mixed with PBS and egg whites without a probiotic administration on the control treatment. A daily feed was given $1-2 \%$ of the biomass weight twice a day.

\section{Spawning preparation}

An artificial spawning was performed using an ovaprim injected on muscle below dorsal fin. The ovaprim dose used for the female broodstocks were $0.3 \mathrm{~mL} / \mathrm{kg}$ broodstock, while the male broodstocks were $0.2 \mathrm{~mL} / \mathrm{kg}$ broodstock. The ovaprim hormone injection was given once at 16.00 GMT+7.

\section{Eggs and sperms collection}

The eggs were taken by removing the female broodstock from the media carefully using a wet fabric. The abdomen part was pressed to withdraw the eggs, then the eggs were kept into a dried container. Meanwhile, the sperms were taken by removing the male broodstock from the media carefully, then dissected to remove its gonads and measured. The gonads were cut on one of the lobes and pressed slowly to withdraw the sperms. Sperms were then kept in a polyethylene tube.

\section{Fertilization}

Five grams of eggs from each female broodstock were mixed with $0.2 \mathrm{~mL}$ sperms and incubated into an aquarium. The fertilization rate value was determined after 8 hours of eggs and sperms mixing by counting the fertilized eggs (transparent color) in different five striped glass squares placed randomly, then compared to the total number of eggs. 


\section{Hatching}

The hatching media used were aquaria sized $40 \times 30 \times 20 \mathrm{~cm}$ filled with water at $25-27^{\circ} \mathrm{C}$ and aerated. Hatching process was performed by incubating the fertilized eggs for 24-40 hours. The hatching rate was determined by counting the hatched eggs (larvae) compared to the total number of fertilized eggs.

\section{Water quality}

Water exchange and syphonization (for an aquarium observation) performed in this study were to maintain the water quality. The water quality parameter for catfish culture used was based on Aneesh et al. (2013).

\section{Gonad maturity index}

Treated female broodstocks were artificially spawned and dissected to obtain their gonads. Gonads were measured to obtain the gonad weight data. The gonad maturity index value was determined by comparing the gonad weight against the fish body weight.

\section{Fecundity}

Fecundity was calculated from the measurement of broodstock weight on pre- and post-ovulated period. The egg weight produced from the ovulation process was obtained from the difference of broodstock weight on pre- and post-ovulated period. Eggs produced from the ovulation process were taken and measured as much as $0.1 \mathrm{~g}$, then the egg was counted and multiplied by 10 to obtain the total number of eggs in $1 \mathrm{~g}$.

\section{Matured egg size determination}

The determination of matured egg size was performed by comparing the egg size from matured broodstock on pre-ovulation process against the remaining egg size in broodstock gonads on post-ovulation process. Three matured broodstocks were injected with an ovaprim and the other three broodstocks were injected with a physiological solution as control. Ovaprim and physiological solution were injected on the muscle below dorsal fin, then the broodstocks were reared for 12 hours in the net. Broodstocks those injected with ovaprim underwent ovulation, while in the control did not. Broodstocks were stripped after 12 hours to withdraw the ovulated eggs and dissected to obtain their gonads. The matured eggs were determined by comparing the remaining egg size from ovaprim injected broodstocks against the egg size in the control broodstocks. The frequency distribution of matured eggs was determined by taking 100 eggs, then measured their diameters using a microscope with 40 times magnification. The egg diameter measurement result on each size group was calculated its percentage and created its frequency distribution. Matured egg size was the size that was absent in gonads on the post-ovulation process.

\section{Parameters}

\section{Gonadosomatic index (GSI)}

The gonadosomatic index (GSI) is the relationship of gonad and body weight. GSI was calculated using the following formula (Yalcin, 2001) at a percentage unit:

$$
\text { GSI }=\frac{\text { Gonad weight }}{\text { Body weight }} \times 100
$$

\section{Fecundity}

Fecundity is the total number of eggs produced per broodstock. Fecundity was determined by the following formula:

Fecundity $=$ Total number of eggs $\times$ Ovulated egg weight

\section{Egg diameter measurement}

The egg diameter $(\mu)$ was calculated with:

Egg diameter $=\frac{\text { Ocular micrometer scale }}{\text { Correction factor }} \times 0.01$

\section{Egg diameter frequency distribution}

The egg diameter frequency distribution was obtained from egg diameter data measured using an ocular micrometer and made in a histogram graphic (Jusmaldi et al., 2018).

\section{Fertilization rate $(F R)$}

The fertilization rate (FR) was calculated using a formula (Tilahun et al., 2016):

$$
\mathrm{FR}=\frac{\text { Total number of fertilized eggs }}{\text { Total number of counted eggs }} \times 100
$$

\section{Hatching rate $(H R)$}

The hatching rate (HR) was calculated using the following formula at a percentage unit:

$$
\mathrm{HR}=\frac{\text { Total number of hatched eggs }}{\text { Total number of counted eggs }} \times 100
$$




\section{Water quality}

The water quality parameters measured in this study were temperature, $\mathrm{pH}, \mathrm{DO}$, nitrite, and total ammonia-nitrogen (TAN). The following table presents the units and tools of measured water quality parameters. The water quality standard in this study was based on Aneesh et al. (2013).

Table 2. Water quality parameter units and measurement tools

\begin{tabular}{ccc}
\hline Parameter & Unit & Tool \\
\hline Temperature & ${ }^{\circ} \mathrm{C}$ & Thermometer \\
$\mathrm{pH}$ & - & $\mathrm{pH}$ meter \\
$\mathrm{DO}$ & $\mathrm{mg} / \mathrm{L}$ & DO meter \\
$\mathrm{NH}_{3}$ & $\mathrm{mg} / \mathrm{L}$ & Spectrophotometer \\
\hline
\end{tabular}

\section{Data analysis}

Data result for fecundity and GSI were analyzed using SPSS 18.0 continued with a Duncan test with the significance level of $\alpha=5 \%$. The data of total matured eggs, frequency distribution, egg diameter, fertilization rate, hatching rate, and water quality were analyzed descriptively using Microsoft Excel 2010.

\section{RESULT AND DISCUSSION}

Result

Gonadosomatic index (GSI)

The observation result of female catfish broodstock gonadosomatic index (GSI) fed with probiotic Bacillus sp. NP5 is presented on Figure 1. The GSI value of female catfish broodstock started to become significantly different at the $6^{\text {th }}$ week with the highest value was obtained from $10^{10} \mathrm{CFU} / \mathrm{mL}(\mathrm{C})$ probiotic concentration (5.19\%). The highest GSI value at the $9^{\text {th }}$ week was obtained from $10^{8} \mathrm{CFU} / \mathrm{mL}$ (B) probiotic concentration with $2 / 49 \%$. The GSI value at the $12^{\text {th }}$ week did not increase followed with an insignificant difference among treatments.

\section{Fecundity}

The observation result of catfish broodstock fecundity level fed with different concentrations of probiotic Bacillus sp. NP5 is presented on Figure 2. All treatment fecundity levels at the end of the study showed a significantly different result $(\mathrm{P}<0.05)$. The highest fecundity level was obtained from the probiotic Bacillus sp. NP5 concentration of $10^{10} \mathrm{CFU} / \mathrm{mL}$ (C) with

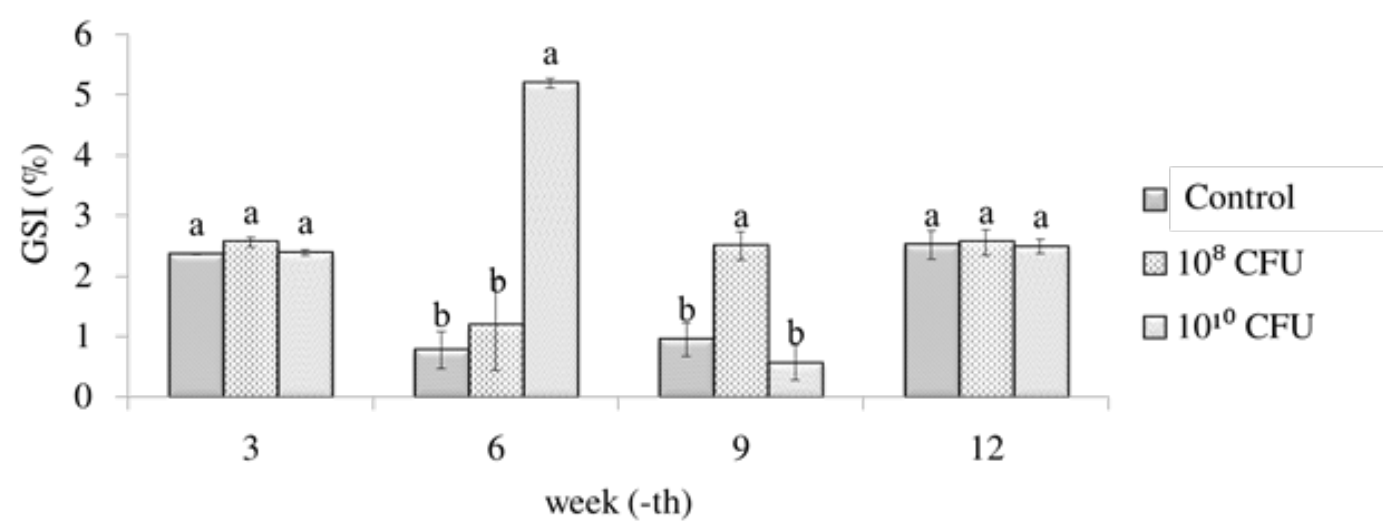

Figure 1. Gonadosomatic index (GSI) of catfish Clarias sp. broodstock fed with the different concentrations of probiotic Bacillus NP5.

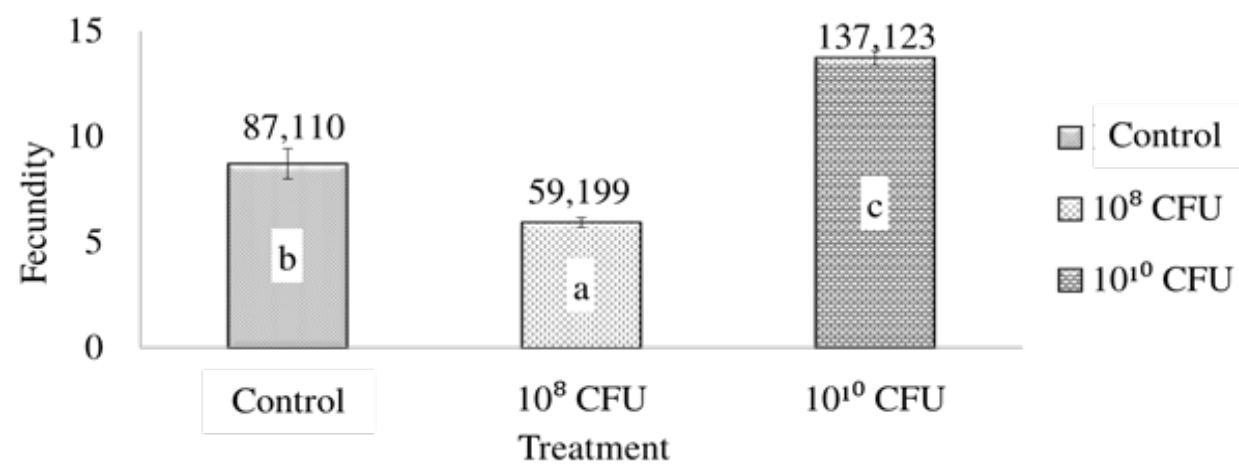

Figure 2. Fecundity level of catfish bloodstock Clarias sp. fed with different concentrations of probiotic Bacillus sp. NP5 
$137,123 \pm 32,635$ eggs/broodstock, followed with the control treatment (A) with $87,110 \pm 29,260$ eggs/broodstock and the lowest was on $10^{8} \mathrm{CFU} /$ $\mathrm{mL}$ (B) with 59,199 $\pm 38,781$ eggs/broodstock.

\section{The total number of matured eggs}

Observation result of egg diameter to evaluate the total number of matured egg development is presented on Table 3. The highest matured egg percentage at the $3^{\text {rd }}$ week was on the probiotic Bacillus sp. NP5 concentration treatment of $10^{8} \mathrm{CFU} / \mathrm{mL}$ (B) with $49.75 \%$, followed with the control treatment $(37.25 \%)$ and probiotic Bacillus sp. NP5 concentration of $10^{10} \mathrm{CFU} / \mathrm{mL}$ (C) $(33,50 \%)$. The percentage of matured eggs increased at the $6^{\text {th }}$ until $12^{\text {th }}$ week with a greater value of probiotic administrations than control. Catfish broodstock fed with $10^{8} \mathrm{CFU} / \mathrm{mL}(\mathrm{B})$ probiotic Bacillus NP5 at the $12^{\text {th }}$ week had the highest percentage $(74.00 \%)$ on the total number of matured eggs, followed with $10^{10} \mathrm{CFU} / \mathrm{mL}$ (C) probiotic Bacillus sp. NP5 (64.50\%) and control (A) $(64.00 \%)$.

\section{Frequency distribution of egg diameter}

The egg diameter frequency distribution of catfish fed with different concentrations of probiotic Bacillus sp. NP5 is presented on Figure 3 . Figure 3 a shows a frequency distribution of catfish at $0^{\text {th }}$ week as the initial study period. The development shows two inclined peaks of egg size at the $3^{\text {rd }}$ week (Figure $3 b$ ) until $9^{\text {th }}$ week (Figure $3 \mathrm{~d})$. However, probiotic Bacillus sp. NP5 with $10^{8}$ $\mathrm{CFU} / \mathrm{mL}$ concentration at the $12^{\text {th }}$ week (Figure 3e) shows a declined peak of immatured egg size. Nevertheless, a large egg size was occurred during this week $(1.17 \mathrm{~mm})$ with $6.5 \%$ occurrence on $10^{10} \mathrm{CFU} / \mathrm{mL}$ (C) probiotic Bacillus sp. NP5 treatment, $5 \%$ on $10^{8} \mathrm{CFU} / \mathrm{mL}$ (B) probiotic Bacillus sp. NP5 treatment, and only $0.75 \%$ on control treatment.

\section{Fertilization rate $(F R)$}

The fertilization rate (FR) value of catfish broodstock eggs fed with different concentrations of probiotic Bacillus sp. NP5 is presented on Figure 4 . The fertilization rate values in this study were insignificantly different. Control treatment (A) obtained $99.14 \%$, probiotic treatment with $10^{8}$ CFU/g concentration (B) obtained $97.59 \%$, and probiotic treatment with $10^{10} \mathrm{CFU} / \mathrm{g}$ concentration (C) obtained $96.82 \%$.

\section{Hatching rate (HR)}

The hatching rate of catfish broodstock eggs fed with different concentrations of probiotic Bacillus sp. NP5 is presented on Figure 5. Based on Figure 5, the highest hatching rate value (HR) was obtained from the administration of $10^{10} \mathrm{CFU} /$ $\mathrm{g}(\mathrm{C})$ probiotic Bacillus sp. NP5 with $82.53 \%$.

\section{Water quality}

Result of water quality measurement during broodstock rearing and egg hatching period of catfish fed with different concentrations of probiotic Bacillus sp. NP5 is presented on Table 4. Data in Table 4 showed that all of water quality parameters, i.e. temperature, dissolved oxygen, $\mathrm{pH}$, and $\mathrm{NH}_{3}$ were in the normal range.

Table 3. Matured egg percentage of female catfish Clarias sp. fed with different concentrations of probiotic Bacillus sp. NP5

\begin{tabular}{ccccc}
\hline \multirow{2}{*}{ Treatment } & \multicolumn{4}{c}{ Matured egg percentage $(>0.85 \mathrm{~mm})$} \\
\cline { 2 - 5 } & $3^{\text {rd }}$ week & $6^{\text {th }}$ week & $9^{\text {th }}$ week & $12^{\text {th }}$ week \\
\hline A $($ Control $)$ & 37.25 & 42.75 & 34.50 & 64.00 \\
B $\left(10^{8} \mathrm{CFU} / \mathrm{mL}\right)$ & 49.75 & 45.00 & 52.50 & 74.00 \\
$\mathrm{C}\left(10^{10} \mathrm{CFU} / \mathrm{mL}\right)$ & 33.50 & 43.75 & 35.50 & 64.50 \\
\hline
\end{tabular}

Table 4. Water quality during the catfish broodstock rearing and egg hatching period

\begin{tabular}{ccccc}
\hline \multirow{2}{*}{ Parameter } & Broodstock & Hatching & \multicolumn{2}{c}{ Standard (Aneesh et al., 2013) } \\
\cline { 3 - 4 } & & & Broodstock & Hatching \\
\hline Suhu $\left({ }^{\circ} \mathrm{C}\right)$ & $27.38 \pm 0.36$ & $27.90 \pm 1.08$ & $26 \pm 3.2$ & $27 \pm 1.79$ \\
$\mathrm{DO}(\mathrm{mg} / \mathrm{L})$ & $4.70 \pm 1.79$ & $6.26 \pm 1.33$ & $5.0 \pm 2.6$ & $6.0 \pm 2.2$ \\
$\mathrm{pH}($ unit) & $7.41 \pm 1.41$ & $8.06 \pm 0.05$ & $7 \pm 0.85$ & $7 \pm 1.26$ \\
$\mathrm{NH}_{3}$ & $0.06 \pm 0.07$ & $0.02 \pm 0.02$ & $0.06 \pm 0.07$ & $0.08 \pm 0.08$ \\
\hline
\end{tabular}



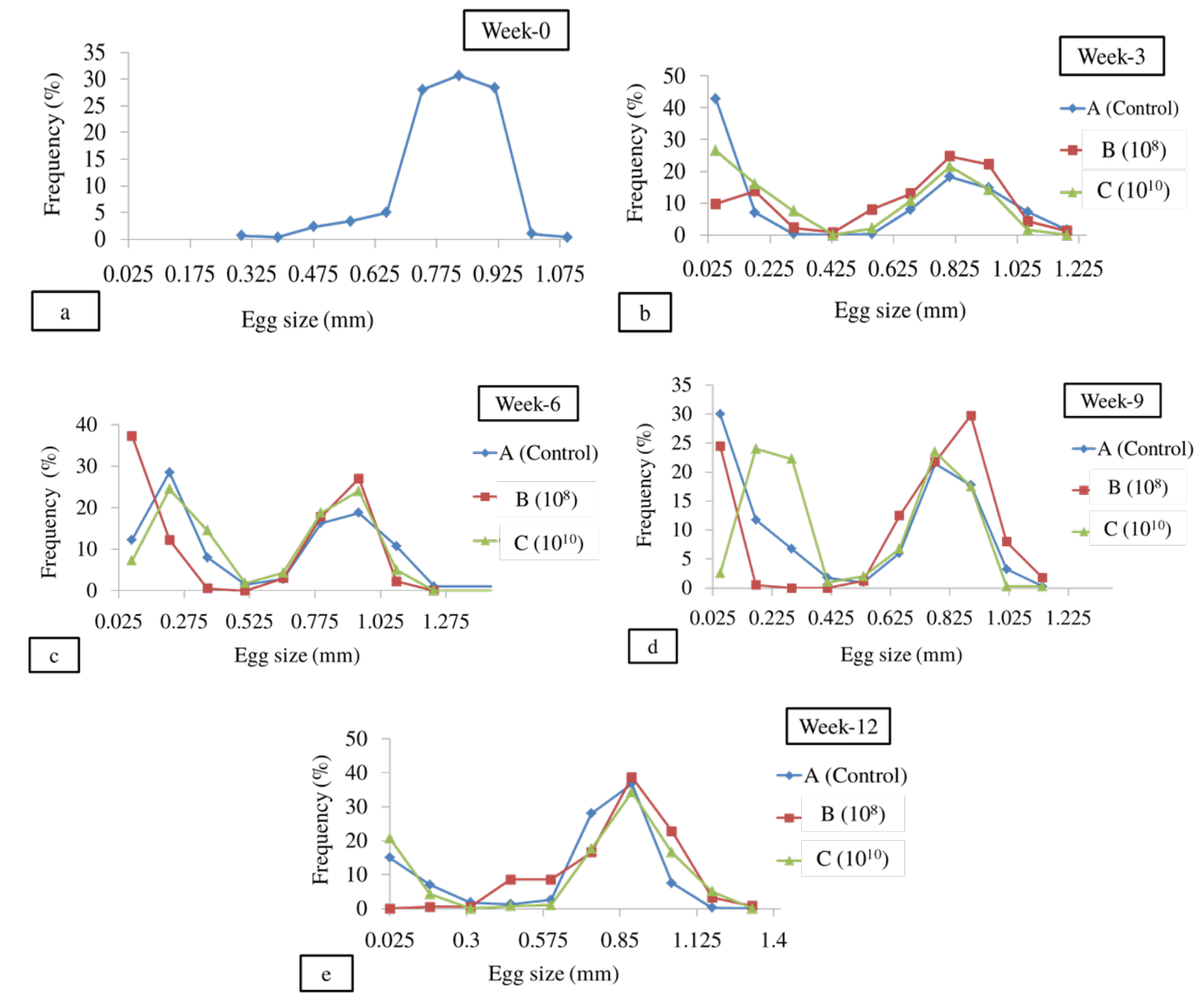

Figure 3. Frequency distribution of catfish Clarias sp. egg diameter fed with different concentrations of probiotic Bacillus sp. NP5 at the $0^{\text {th }}$ week (a), $3^{\text {rd }}$ week (b), $6^{\text {th }}$ week (c), $9^{\text {th }}$ week (d), and $12^{\text {th }}$ week (e) of rearing period.

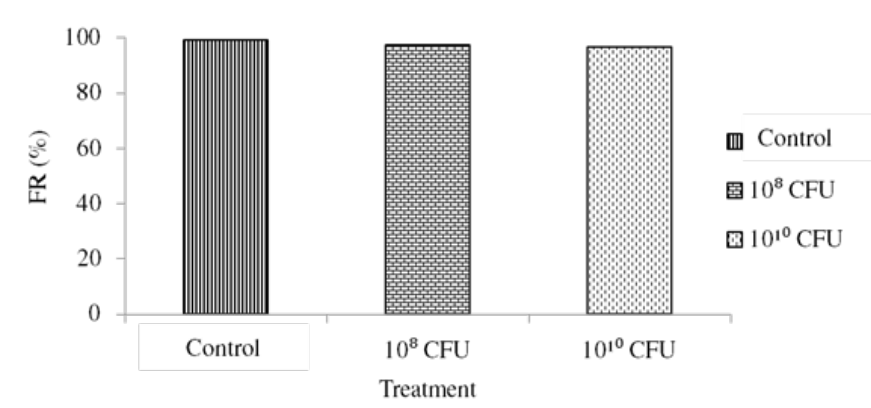

Figure 4. Egg fertilization rate of catfish Clarias sp. fed with different concentrations of probiotic Bacillus sp. NP5

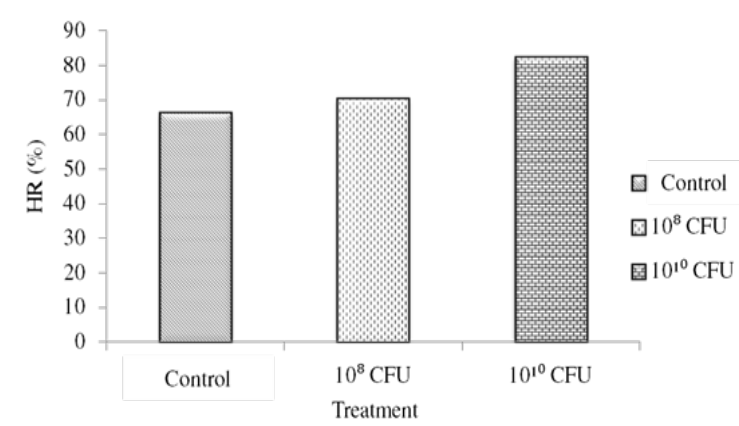

Figure 5. Hatching rate of catfish Clarias sp. eggs on different treatment concentrations of probiotic Bacillus sp. NP5 


\section{Discussion}

Gonadosomatic index (GSI) reflects the relationship between gonad and body weight. Based on Figure 1, the GSI value of female catfish broodstock was significantly different at the 6th week with the highest value was on $10^{10} \mathrm{CFU} / \mathrm{mL}(\mathrm{C})$ probiotic treatment, namely $5.19 \%$. Increased GSI value was similar to the study result of Gioacchini et al. (2011), which showed that the probiotic administration of Lactobacillus rhamnosus IMC $501^{\circledR}$ on zebra fish had a higher GSI value than the control treatment. Moreover, Gioacchini et al. (2011) explained that the increased GSI value happened due to the increased estradiol receptors (ero) and $v t g$ gene expression correlated with the significant inclination of cyp19a gene expression. The expression of cyp 19a gene indicate an enzyme activity controlling the androgenic to estrogenic alteration, therefore the inclined cyp19a genes can increase the estradiol level in blood plasma, which continuously increases vitellogenins (vtg) in vitellogenesis process. The highest GSI value at the $9^{\text {th }}$ week was obtained from $10^{8} \mathrm{CFU} / \mathrm{mL}$ (B) probiotic treatment with $2.49 \%$. Decreased GSI value at the $9^{\text {th }}$ week on the $10^{10} \mathrm{CFU} / \mathrm{mL}$ (C) probiotic treatment was suspected due to the over-riped eggs. The GSI value at the $12^{\text {th }}$ week did not increase again following the treatments. This was suspected because the nutrient content in probiotics after the $9^{\text {th }}$ week was insufficient for the broodstock to improve the reproduction performance.

Fecundity is the broodstock capability of producing eggs that are ready to be spawned. Fecundity is closely related to the vitellogenesis process, namely the egg yolk synthesis and filling the yolk into the egg (Gioacchini et al., 2011). The increase in fecundity was suspected due to the probiotics indirectly inactivates the potential hormone in metabolism, such as leptins. Increased leptin levels are correlated with high expressions of kiss 1, kiss2, and also GnRH3 gene in the female brain given treatment, improving the fecundity level. Leptins regulate the reproduction in hypothalamus by modulating the mRNA transcription and GnRH release, as well as in hypophysis by modulating $L H$ gene expression release (Gioacchini et al., 2010). The present study found that the fecundity level (Figure 2) on all treatments at the final study period showed a significantly different result $(\mathrm{P}<0.05)$. The highest fecundity level was found on $10^{10} \mathrm{CFU} / \mathrm{mL}$ (C) probiotic Bacillus sp. NP5 with 137,123 $\pm 32,635$ eggs/broodstock, followed with control treatment (A) 87,110 $\pm 29,260$ eggs/broodstock, and the lowest was on $10^{8} \mathrm{CFU} / \mathrm{mL}$ (B) probiotic Bacillus sp. NP5 with 59,199 $\pm 38,781$ eggs/broodstock. Generally, this was in line with the study result of Gioacchini et al. (2010) which indicated that the administration of probiotic L. rhamnosus in zebra fish caused a higher fecundity level than the control treatment.

Female reproduction process is started from the vitellogenesis and finished on the dormant phase as fish awaits for ovulation and spawning signals. According to Sarkar et al. (2014), matured fish eggs have larger size and weight. Based on Table 3, catfish broodstock fed with $10^{8} \mathrm{CFU} / \mathrm{mL}$ (B) probiotic Bacillus sp. NP5 treatment at the $12^{\text {th }}$ week had the highest number of matured egg percentage $(74.00 \%)$, followed with $10^{10} \mathrm{CFU} /$ $\mathrm{mL}$ (C) probiotic Bacillus sp. NP5 (64,50\%) and control (A) $(64.00 \%)$. This value indicated that administration of probiotic Bacillus sp. NP5 in feed increase egg yolk content and then increasing the total number of matured eggs. The number of matured eggs can be predicted through a frequency distribution of egg diameter. The result of catfish egg diameter frequency distribution after fed with different concentrations of probiotic Bacillus sp. NP5 is presented on Figure 3. Figure 3a shows a frequency distribution of catfish at $0^{\text {th }}$ week (initial study period). The development shows two inclined peaks of egg size at the $3^{\text {rd }}$ week (Figure 3b) until $9^{\text {th }}$ week (Figure 3d). This result was similar to the study result of Tyor and Pahwa (2017) which stated that the existence of egg diameter similarity at third and fourth level was found to be capable of spawning at several times in a year.

However, probiotic Bacillus sp. NP5 with $10^{8}$ $\mathrm{CFU} / \mathrm{mL}$ concentration at the 12 th week (Figure 3e) shows a declined peak of immatured egg size. A large egg size was occurred during this week $(1.17 \mathrm{~mm})$ with $6.5 \%$ occurrence on $10^{10} \mathrm{CFU} /$ $\mathrm{mL}$ (C) probiotic Bacillus sp. NP5 treatment, 5\% on $10^{8} \mathrm{CFU} / \mathrm{mL}$ (B) probiotic Bacillus sp. NP5 treatment, and only $0.75 \%$ on control treatment. This indicates that eggs from the broodstock fed with probiotic Bacillus sp. NP5 have greater size than control.

The fertilization rate value in this study was around 96.82-99.14\% and insignificantly different among probiotic and control treatments. This indicates that the administration of probiotic Bacillus sp. NP5 has no negative effect on the egg quality. Meanwhile, the highest hatching rate was 
found on $10^{10} \mathrm{CFU} / \mathrm{mL}$ probiotic Bacillus sp. NP5 concentration with $82.53 \%$. The hatching rate value on probiotic treatments were higher than control as suspected due to higher gonadosomatic index, resulting more perfect eggs with higher egg yolk content. Egg yolk is an energy source for embryo required for fulfilling the embryonic to hatch (Fajrin et al., 2012).

Some factors influencing eggs and sperms quality come from the environmental factors such as temperature, salinity, and photoperiod. However, temperature becomes the main factor which influences egg quality, especially during the reproductive and spawning season. Low temperature can have a negative impact on the egg quality (Bobe \& Labbe, 2010). In the present study, water quality parameters which consisted of temperature, dissolved oxygen (DO), $\mathrm{pH}$, and $\mathrm{NH}_{3}$ were still in the normal range.

\section{CONCLUSION}

The administration of probiotic Bacillus sp. NP5 with $10^{10} \mathrm{CFU} / \mathrm{mL}$ concentration through feed on catfish (Clarias sp.) broodstock could increase the fecundity level (137,123 eggs/ broodstock), GSI (5.19\%), percentage of matured egg $(64.50 \%)$, and hatching rate $(82.53 \%)$.

\section{ACKNOWLEDGEMENTS}

Authors would like to thank the head of Catfish and Striped Catfish Development and Stock Inducement Center, Cijengkol, Subang, West Java for providing the materials in this study and West Java Province stakeholders for funding support through Beasiswa Pemprov Jabar in 2016.

\section{REFERENCES}

Aneesh B, Salin KR, Nair CM. 2013. Breeding for conservation: case of an endangered catfish, Clarias dussumieri (Valenciennes, 1840). Fishery Technology 50: 101-109.

Bobe J, Labbe C. 2010. Egg and sperm quality in fish. General and Comparative Endocrinology 165: 535-548.

Cruz PM, Ibanez AL, Hermosillo OAM, Saad HCR. 2012. Review articles use of probiotics in aquaculture. International Scholarly Research Network ISRN Microbiology 1-13.
Ekasari J, Zairin Jr M, Putri DU, Sari NP, Surawidjaja EH, Bossier P. 2015. Bioflocbased reproductive performance of Nile tilapia Oreochromis niloticus L. broodstock. Aquaculture Research 46: 509-512.

Emerenciano M, Cuzon G, Arevalo M, Gaxiola G. 2014. Biofloc technology in intensive broodstock farming of the pink shrimp Farfantepenaeus duorarum: spawning performance, biochemical composition and fatty acid profile of eggs. Aquaculture Research 45: 1713-1726.

Emerenciano M, Cuzon G, Goguenheim J, Gaxiola G. 2012. Floc contribution on spawning performance of blue shrimp Litopenaeus stylirostris. Aquaculture Research 44: 75-85.

Fajrin CN, Ibnu DB, Sriati. 2012. Penambahan ekstrak tauge dalam pakan untuk meningkatkan keberhasilan pemijahan ikan mas koki Carrasius auratus. Jurnal Perikanan dan Kelautan 3: 51-60.

Gioacchini G, Lombardo F, Merrifield DL, Silvi S, Cresci A, Avelia MA, CarnevaliO.2011. Effects of probiotics on zebrafish reproduction. https:// www.omicsonline.org/effects-of-probioticon-zebrafish-reproduction-2155-9546.S1002.php?aid=1985. [8 Juni 2016].

Gioacchini G, Maradonna F, Lombardo F, Bizzaro D, Olivotto I, Carnevali O. 2010. Increase of fecundity by probiotic administration in zebrafish Danio rerio. Reproduction Research 140: 953-954.

Iswanto B. 2013. Menelusuri identitas ikan lele dumbo. Media Akuakultur 8: 85-95.

Jusmaldi, Solihin DD, Affandi R, Rahardjo MF, Gustiano R. 2018. Kematangan gonad dan tipe pemijahan ikan lais, Ompok miostoma (Vaillant, 1902) di Daerah Aliran Sungai Mahakam Kalimantan Timur. Jurnal Iktiologi Indonesia 17: 201-213.

[KKP] Kementrian Kelautan dan Perikanan. 2017. Laporan Kinerja 2016. Jakarta: Direktorat Jenderal Perikanan Budidaya (DJPB) KKP.

Nadio H. 2015. Biofloc technology during the rematuration period of the African catfish Clarias gariepinus females: effect of temperature and flocs on reproductive performance. [Tesis]. Bogor: Institut Pertanian Bogor.

Nayak SK. 2010. Probiotics and immunity: a fish perspective. Fish \& Shellfish Immunology 29: $2-14$. 
Sarkar S, Bhattacharya D, Juin SK, Nath P. 2014. Biological properties of Indian walking catfish Clarias batrachus (L.) gonadotropin in female reproduction. Fish Physiology and Biochemistry 40: 1849-1861.

Tilahun G, Dube K, Chtruvedi CS, Kumar B. 2016. Assessment of reproductive performance, growth and survival of Hybrids of African catfish Clarias gariepinus and Indian catfish Clarias batrachus compared to their parental lines crosses. Turkish Journal Fisheries and Aquatic Science 16: 123-133.

Tyor AK, Pahwa K. 2017. Ovarian development of African sharptooth catfish Clarias gariepinus
(Burchell 1822) from Delhi segment of river Yamuna. Journal of Fisheries Science 12: 117-126.

Widanarni, Ekasari J, Maryam S. 2012. Evaluation of biofloc technology application on water quality and production performance of red tilapia Oreochromis sp. cultured at different stocking densities. Journal of Biosciences19: 73-80.

Yalcin S.2001.Certain reproductivecharacteristics of the catfish Clarias gariepinus (Burchell, 1822) living in the River Asi, Turkey. Turkish Journal of Zoology 25: 453-460. 